\title{
Netrin-1 Promotes Epithelial Sodium Channel-Mediated Alveolar Fluid Clearance via Activation of the Adenosine 2B Receptor in Lipopolysaccharide-Induced Acute Lung Injury
}

\author{
Jing He Yan Zhao Wang Deng Dao-xin Wang \\ Respiratory Medicine, Second Affiliated Hospital of Chongqing Medical University, Chongqing, China
}

\section{Key Words \\ Netrin-1 - Acute lung injury · Alveolar fluid clearance · Epithelial sodium channel - Adenosine 2B receptor . Cyclic adenosine monophosphate}

\begin{abstract}
Background: The epithelial sodium channel (ENaC) is the driving force for pulmonary edema absorption in acute lung injury (ALI). Netrin-1 is a newly found anti-inflammatory factor that works by activating the adenosine $2 \mathrm{~B}$ receptor (A2BAR). Meanwhile, activated A2BAR has the potential to enhance $\mathrm{ENaC}$-dependent alveolar fluid clearance (AFC). However, whether netrin-1 can increase ENaC-mediated AFC by activating A2BAR remains unclear. Objectives: To investigate the effect of netrin-1 on AFC in ALI and clarify the pathway via which netrin-1 regulates the expression of $\mathrm{ENaC}$ in vivo and in vitro. Methods: An ALI model was established by intratracheal instillation of lipopolysaccharide (LPS; $5 \mathrm{mg} /$ $\mathrm{kg}$ ) in C57BL/J mice, followed by netrin-1 with or without pretreatment with PSB1115, via the caudal vein. Twenty-four hours later, the lungs were isolated for determination of the bronchoalveolar lavage fluid, the lung wet/dry weight (W/D) ratio, AFC, the expressions of $\alpha^{-}, \beta-$, and $\gamma^{-E N a C}$, and cyclic adenosine monophosphate (cAMP) levels. LPS-stimulated MLE-12 cells were incubated with netrin-1 with or without preincubation with PSB1115. Twenty-four hours later, the expressions of $\mathrm{a}^{-}, \boldsymbol{\beta}-$, and $\mathrm{\gamma}$-ENaC were detected. Results: In
\end{abstract}

vivo, netrin-1 expression was significantly decreased during ALI. Substituted netrin-1 significantly dampened the lung injury, decreased the W/D ratio, and enhanced AFC, the expressions of $\alpha-, \beta-$, and $\gamma-E N a C$, and $C A M P$ levels in $A L I$, which were abolished by specific A2BAR inhibitor PSB1 115. In vitro, netrin- 1 increased the expressions of $\alpha_{-}^{-}, \beta-$, and $\gamma^{-E N a C}$, which were prevented by PSB1115. Conclusion: These results indicate that netrin-1 dampens pulmonary inflammation and increases ENaC-mediated AFC to alleviate pulmonary edema in LPS-induced ALI by enhancing CAMP levels through the activation of A2BAR.

(c) 2014 S. Karger AG, Basel

\section{Introduction}

Acute lung injury (ALI) and acute respiratory distress syndrome (ARDS) are critical syndromes resulting in life-threating respiratory failure, with a lethality of around $38 \%$, characterized by acute hypoxemic respiratory failure with protein-rich pulmonary edema that is not attributed to left atrial hypertension [1].

As a primary pathological feature of ALI/ARDS, pulmonary edema induced via alveolar-capillary barrier injury causes severe and stubborn hypoxemia. Timely and effective clearance of the redundant edema fluid in the air spaces is of great importance for the prognosis of ALI/ ARDS [2]. Alveolar fluid clearance (AFC), achieved via

\section{KARGER}

E-Mail karger@karger.com

www.karger.com/res
C 2014 S. Karger AG, Basel

0025-7931/14/0875-0394\$39.50/0
Dao-xin Wang

Respiratory Medicine, Second Affiliated Hospital of Chongqing Medical University 76 Linjiang Road

Yuzhong District, Chongqing 400010 (China)

E-Mail wangdaoxin1@163.com 
determination of the alveolar fluid volume in vivo, is seriously impaired in ALI/ARDS [3]. With expression on both alveolar type I and type II cells, the amiloride-sensitive epithelial sodium channel $(\mathrm{ENaC})$, which is a heteromultimeric protein consisting of 3 homologous subunits $(\alpha, \beta$, and $\gamma)$, is widely believed to play a critical role in AFC [4]. When edema fluid is reabsorbed, $\mathrm{Na}^{+}$enters the epithelium through the $\mathrm{ENaC}$ at the apical membrane and then exits at the basolateral membrane through $\mathrm{Na}^{+}-$ $\mathrm{K}^{+}$-ATPase. The osmotic pressure gradient induced by the concentration change of the $\mathrm{Na}^{+}$causes the reabsorptive drive of $\mathrm{H}_{2} \mathrm{O}$ [5]. Failing to clear the alveolar fluid, neonatal $\alpha E N a C$ gene knockout mice develop respiratory distress and die within $40 \mathrm{~h}$ of birth [6]. The $\beta$ and $\gamma$ subunits are necessary for the formation of a functional channel to maximize the AFC $[7,8]$. Therefore, the 3 subunits of $\mathrm{ENaC}$ are all indispensable for efficient AFC. However, they are all badly impaired when ALI/ARDS occurs.

The neuronal guidance protein netrin-1 is secreted by the neural floor plate, which is initially identified in the central nervous system during neuronal development, controlling axonal growth and growth cone migration [9]. It is also widely expressed outside the central nervous system in the lung $[10,11]$, pancreas $[12,13]$ and mammary glands [14]. In previous studies, netrin-1 has been shown to have the capacity to alleviate the inflammatory response in acute inflammation as a potential anti-inflammatory protein, by activating the adenosine $2 \mathrm{~B}$ receptor (A2BAR) $[15,16]$. Coincidentally, stimulation of A2BAR has been proven to enhance AFC to attenuate ALI in mice by upregulating cyclic adenosine monophosphate (cAMP) $[17,18]$. However, whether netrin-1 can increase AFC and alleviate pulmonary edema in ALI/ ARDS remains unknown. We were greatly interested in investigating whether netrin-1 could simultaneously increase $\mathrm{ENaC}$-mediated AFC in ALI/ARDS.

In this study, we focused on the effect of netrin-1 on lipopolysaccharide (LPS)-induced ALI in mice, especially in terms of AFC and the expression of ENaC. We hypothesized that netrin-1 would alleviate lung injury in LPSinduced ALI, accelerate AFC, and attenuate pulmonary edema by enhancing the expression of $\mathrm{ENaC}$ via the activation of A2BAR.

\section{Materials and Methods}

\section{Animals and Study Design}

All animal care and treatment procedures were approved by the Chongqing Medical University Animal Care Center and performed in accordance with the Ethics Committee of the Second
Affiliated Hospital of Chongqing Medical University. Adult male C57BL/6J mice weighing 20-25 g were provided by the Animal Centre of Chongqing Medical University. The mice were housed under specific pathogen-free conditions in a temperature- and humidity-controlled environment and were given free access to food and water. The mice were randomly divided into 4 groups as follows: control group, LPS group, LPS+netrin-1 group (LN group), and LPS+PSB1115+netrin-1 group (LPN group).

\section{Main Reagents}

Human netrin-1 was obtained from R\&D Systems (Minneapolis, Minn., USA). Anti-netrin- 1 , anti- $\alpha-$, anti- $\beta-$, and anti- $\gamma$-ENaC, and anti- $\beta$-actin primary antibodies were all purchased from $A b$ cam (Cambrige, UK). Specific A2BAR inhibitor PSB1115 was purchased from Santa Cruz Biotechnology (Santa Cruz, Calif., USA). Lipopolysaccharide (Escherichia coli serotype 055:B5), sodium pentobarbital, and Evans Blue were purchased from Sigma (St. Louis, Mo., USA). RNAiso plus, the PrimeScript RT Reagent Kit, and Premix Taq version 2.0 were purchased from TaKaRa Biotechnology (Dalian) Co., Ltd. (Dalian, China).

\section{LPS-Induced ALI Model in Mice}

Mice were anesthetized with $50 \mathrm{mg} / \mathrm{kg}$ sodium pentobarbital via intraperitoneal injection, followed by $5 \mathrm{mg} / \mathrm{kg}$ LPS in $50 \mu \mathrm{l} \mathrm{ster-}$ ile saline intratracheal injection with an indwelling vein needle [19]. The animals in the control group were given an equal amount of saline instead. One microgram of netrin-1 in $50 \mu$ l saline (LN group and LPN group) or saline (control group and LPS group) was given via caudal vein injection immediately after LPS administration. In the LPN group, $10 \mathrm{mg} / \mathrm{kg}$ PSB 1115 was injected via the caudal vein 30 min before netrin- 1 administration. After resuscitation, the mice were housed as previously mentioned. The animals were sacrificed after $24 \mathrm{~h}$ and lungs were removed for the next experiments.

\section{Bronchoalveolar Lavage Fluid}

The bronchoalveolar lavage fluid (BALF) was acquired according to the established procedure $[20,21]$. Briefly, mice were anesthetized with sodium pentobarbital $(50 \mathrm{mg} / \mathrm{kg})$ and their tracheas and lungs were exposed. A catheter was intubated into the main trachea and bronchoalveolar lavage was performed with a 1-ml syringe via 3 cycles of instillation and aspiration with $1 \mathrm{ml}$ saline every time. More than $90 \%$ of the BALF was collected from each mouse and centrifuged at $800 \mathrm{rpm}$ for $10 \mathrm{~min}$ at $4^{\circ} \mathrm{C}$ to remove cell debris. The supernatants were stored at $-80^{\circ} \mathrm{C}$ for further research. The sediments were resuspended in $50 \mu \mathrm{l}$ PBS and stained with Wright-Giemsa (KeyGen Biotech Co., Nanjing, China) for total cell and neutrophil counts.

Total Protein, Tumor Necrosis Factor- $\alpha$, and Interleukin-1 $\beta$ Levels and Myeloperoxidase Assay in BALF

The total protein in BALF was determined with the supernatant using a protein assay kit (KeyGen Biotech). The measurements of tumor necrosis factor (TNF)- $\alpha$ and interleukin (IL)- $1 \beta$ were analyzed using enzyme-linked immunosorbent assay (ELISA) kits (R\&D Systems). The assay ranges of the two kits were 10.9-700 pg/ $\mathrm{ml}$ and $12.5-800 \mathrm{pg} / \mathrm{ml}$, respectively. Myeloperoxidase (MPO) activity was determined using an MPO assay kit (Nanjing Jiancheng Bioengineering Institute, Nanjing, China). All kits were used according to the manufacturers' instructions. 


\section{Lung Wet/Dry Weight Ratio}

The lung wet/dry weight (W/D) ratio was used to assess pulmonary edema $[17,22]$. Right lower lungs were isolated for determination of the W/D ratios. The wet weight of each isolated lung was determined and then the lung was placed in an oven at $80^{\circ} \mathrm{C}$. Forty-eight hours later, the lung was weighed again to obtain its dry weight.

\section{Alveolar Fluid Clearance}

AFC was measured by the change in alveolar Evans Blue-labeled albumin concentrations $[23,24]$. Briefly, after integral removal of the lung, $1 \mathrm{ml}$ warm saline containing Evans Blue dyelabeled 5\% albumin was injected into it. Then $2 \mathrm{ml}$ oxygen was injected to distribute the saline evenly in the alveolar spaces. The lungs were incubated at $37^{\circ} \mathrm{C}$ and inflated at an airway pressure of $7 \mathrm{~cm} \mathrm{H}_{2} \mathrm{O}$ with oxygen for $1 \mathrm{~h}$. AFC was calculated as follows:

$$
\mathrm{AFC}=[(\mathrm{Vi}-\mathrm{Vf}) / \mathrm{Vi}] \times 100 \% \mathrm{Vf}=(\mathrm{Vi} \times \mathrm{Ei}) / \mathrm{Ef}
$$

$\mathrm{V}$ represents the volume of injected albumin solution (i) and final alveolar fluid (f), and E represents the injected (i) and final (f) concentrations of Evans Blue-labeled 5\% albumin solution.

\section{Lung Histology Evaluation}

The left lungs were harvested and fixed in $4 \%$ paraformaldehyde for $24 \mathrm{~h}$. After dehydration with gradient ethanol and vitrification with xylene, they were embedded in paraffin and 5- $\mu \mathrm{m}$ sections were prepared. Paraffin sections were stained with hematoxylin and eosin (H\&E) for observation under an optical microscope. A semiquantitative scoring system with a scale of 0 to 4 points according to combined assessments of inflammatory cell infiltration, alveolar septa thickness, intra-alveolar and interstitial edema, and hemorrhage was used to assess the lung injury. A score of 0 represented no injury, 1 represented slight injury, 2 represented moderate injury, 3 represented severe injury, and 4 represented very severe injury [25].

\section{Immunohistochemistry}

The paraffin sections were dewaxed with xylene and hydrated with gradient ethanol, and then placed in $3 \% \mathrm{H}_{2} \mathrm{O}_{2}$ for 10 min to inhibit endogenous peroxidase activity and rinsed with phosphate buffer solution (PBS; pH 7.6). They were blocked with serum albumin for $1 \mathrm{~h}$ at $37^{\circ} \mathrm{C}$ and incubated with primary antibodies at $4^{\circ} \mathrm{C}$ overnight. The next day, after washing with PBS 3 times, the sections were treated with biotinylated IgG (Santa Cruz Biotechnology) for $15 \mathrm{~min}$ at $37^{\circ} \mathrm{C}$. After rinsing with PBS 3 times, they were reacted with avidin-biotin-peroxidase complex (Sigma) for 15 min and then stained with DAB (Sigma) for $30 \mathrm{~s}$. Next, they were dyed with hematoxylin for $3 \mathrm{~min}$. After dehydration with ethanol and vitrification with xylene, the sections were sealed with neutral resins. Normal rabbit isotype IgG (Santa Cruz Biotechnology) was a substitute for the primary antibodies as a negative control. Via light microscopy, the number of positive cells was counted in 5 random high-power fields (magnification $\times 400$ ) of each section and averaged.

\section{Cell Culture and Treatments}

MLE-12 cells [American Type Culture Collection (ATCC), CRL-2110], a cell line derived from murine alveolar epithelial cells $[26,27]$, were seeded onto plastic culture dishes and cultured in a $37^{\circ} \mathrm{C}, 5 \% \mathrm{CO}_{2}$ atmosphere in Hites media containing $10 \%$ fetal bovine serum, $100 \mathrm{U} / \mathrm{ml}$ penicillin, and $0.1 \mathrm{mg} / \mathrm{ml}$ streptomycin. Upon $80 \%$ confluence, solutions were administered after overnight starvation as follows: (1) control group, equal sterile PBS; (2) LPS group, LPS (100 ng/ml) [28, 29]; (3) LPS+netrin-1 group, LPS (100 ng/ml) + netrin-1 (500 ng/ml) [30], and (4) PSB1115+LPS+netrin-1 group, PSB1115 (1 $\mu \mathrm{M}$ [31], $30 \mathrm{~min}$ before LPS $)+$ LPS $(100 \mathrm{ng} / \mathrm{ml})+$ netrin-1 $(500 \mathrm{ng} / \mathrm{ml})$. Twenty-four hours later, cells were collected and further experiments were performed.

\section{RNA Extraction and Reverse Transcription Polymerase Chain} Reaction Analysis

Total RNA was extracted from lung tissues or MLE-12 cells with an RNA extraction kit. The concentration and purity of the RNA were estimated on a spectrophotometer. The primer sequences used for polymerase chain reaction (PCR) amplification were as explained below.

RNA reverse transcription was performed using a PrimeScript RT Reagent Kit. The reverse transcription reaction conditions were $37^{\circ} \mathrm{C}$ for $15 \mathrm{~min}$ and $85^{\circ} \mathrm{C}$ for $5 \mathrm{~s}$. PCR comprised predenaturation at $94^{\circ} \mathrm{C}$ for $5 \mathrm{~min}, 30$ cycles of denaturation at $94^{\circ} \mathrm{C}$ for $30 \mathrm{~s}$, annealing at $57.8^{\circ} \mathrm{C}(\alpha-\mathrm{ENaC}), 57.8^{\circ} \mathrm{C}(\beta-\mathrm{ENaC}), 57.0^{\circ} \mathrm{C}$ $\left(\gamma\right.$-ENaC), and $57.4^{\circ} \mathrm{C}(\beta$-actin) for $30 \mathrm{~s}$, and polymerization at $72^{\circ} \mathrm{C}$ for $30 \mathrm{~s}(\alpha-, \beta$-, and $\gamma$-ENaC) or $40 \mathrm{~s}$ ( $\beta$-actin) using Premix Taq version 2.0. Agarose gel electrophoresis was performed with each PCR product on a $2.5 \%$ agarose gel containing gold view and visualized using the Gel Imaging System (Bio-Rad, Hercules, Calif., USA).

\section{Protein Extraction and Western Blot Analysis}

Proteins were obtained using RIPA lysis buffer and phenylmethanesulfonyl fluoride according to the manufacturer's instructions. The concentration of each protein sample was determined using a BCA protein assay kit (KeyGen Biotech). Proteins $(50 \mu \mathrm{g})$ were separated by electrophoresis on $8 \%$ SDS-PAGE and transferred to polyvinylidene fluoride membranes. After blocking with $5 \%$ nonfat milk in PBS containing $0.05 \%$ Tween 20 (PBST) for $1 \mathrm{~h}$, the membranes were incubated with anti-netrin- 1 , anti- $\alpha-$, anti- $\beta-$, and anti- $\gamma$-ENaC, and $\beta$-actin (all 1:1,000 dilution) primary antibodies, respectively, overnight at $4^{\circ} \mathrm{C}$. The next day, they were washed with PBST 3 times (10 min each time), reacted with horseradish peroxidase-conjugated secondary antibody (1:5,000 dilution) at $37^{\circ} \mathrm{C}$ for $1 \mathrm{~h}$, and washed 3 times again. Using an enhanced chemiluminescence method, protein bands were detected with a UVP gel imaging system (Upland, Calif., USA) and analyzed using Quantity One software.

\section{cAMP Levels in Lungs}

Lung samples were treated with isobutyryl methylxanthine (Sigma) to inhibit phosphodiesterases, homogenized in ice-cold $1 \mathrm{M}$ TCA, and then centrifuged at 2,500 $\mathrm{g}$ to precipitate particulate material. The cAMP content in the supernatant was measured via ELISA according to the manufacturer's instructions (R\&D Systems). The assay range of this kit was $31.2-2,000 \mathrm{pg} / \mathrm{ml}$.

\section{Statistic Analysis}

All data are presented as means \pm SD. Statistical analysis was performed using one-way analysis of variance (ANOVA) and paired t tests with SPSS 19.0 software (SPSS Inc., Chicago, Ill., USA). $\mathrm{p}<0.05$ was considered statistically significant. 


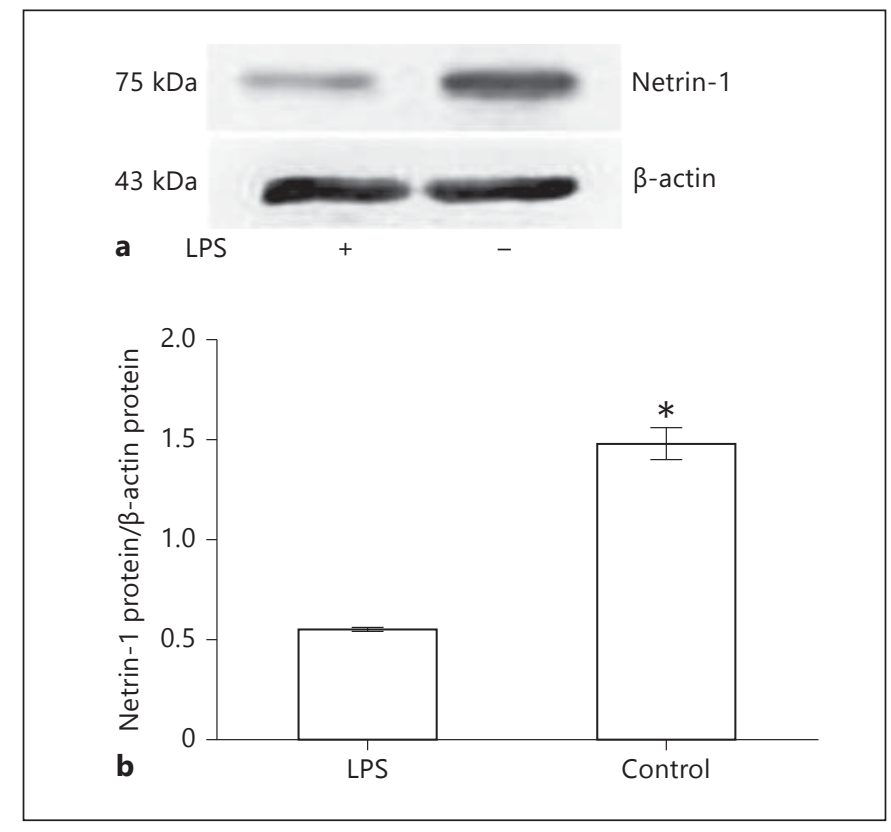

Fig. 1. Endogenous netrin-1 expression in the mouse lung was detected by Western blotting $24 \mathrm{~h}$ after LPS or saline administration (a) $\left(\mathrm{n}=5\right.$ per group). Data are presented as means \pm SD. ${ }^{*} \mathrm{p}<0.05$ compared to the control group (b).

\section{Results}

\section{Pulmonary Netrin-1 Is Reduced during ALI in vivo}

Twenty-four hours after intratracheal exposure to LPS, we detected endogenous netrin-1 protein levels in the lung. We found significantly repressed netrin-1 protein levels in pulmonary tissue in the LPS group compared to the control group ( $\mathrm{p}<0.05$; fig. $1 \mathrm{a}, \mathrm{b}$ ).

\section{Netrin-1 Attenuated Lung Injury in vivo}

To assess the pathological changes elicited by LPS, $\mathrm{H} \& \mathrm{E}$ staining and lung injury marking criteria were used. Twenty-four hours after LPS intratracheal instillation, histological evaluation of the lung manifested conspicuous inflammatory cell infiltration, alveolar septa thickening, and intra-alveolar and interstitial edema. Exogenous netrin-1 significantly attenuated the pathological changes caused by LPS ( $\mathrm{p}$ < 0.05). However, the specific A2BAR inhibitor PSB1115 blocked the effect of netrin-1 significantly $(\mathrm{p}<0.05)$ (fig. 2a, b).

Netrin-1 Decreased TNF- $\alpha, I L-1 \beta$, Protein Levels, and Neutrophil Infiltration in BALF during ALI

To further investigate the anti-inflammatory effect of netrin- 1 , we compared the TNF- $\alpha$, IL- $1 \beta$, protein levels, and neutrophil counts in BALF. Twenty-four hours after LPS instillation, the TNF- $\alpha$, IL- $1 \beta$, protein levels, and neutrophil counts in BALF were significantly decreased in the LN group compared to the LPS group ( $p<0.05$; fig. 3a-f). However, the effect of netrin-1 was abolished by PSB1115 ( $<<0.05$; fig. 3a-f).

Netrin-1 Alleviated Lung Edema and Accelerated AFC in LPS-Induced ALI

The $\mathrm{W} / \mathrm{D}$ ratio is a common method used to assess the severity of pulmonary edema, and AFC is generally used to estimate the capacity of the lung to remove edema fluid. In LPS-induced ALI mice, the W/D ratio significantly decreased with exogenous netrin-1 treatment. The netrin-1-induced decrease in $\mathrm{W} / \mathrm{D}$ was significantly blocked by PSB1115 ( $p<0.05$; fig. 4a). AFC significantly increased with netrin-1 administration but was inhibited by PSB1115 or amiloride ( $<<0.05$; fig. 4b).

\section{Effect of Netrin-1 on the Localization of ENaC in}

\section{LPS-Induced ALI}

Immunohistochemistry was used to determine the localization of $\alpha-, \beta$-, and $\gamma$-ENaC in the mouse lung after LPS or saline administration. Positively immunostained cells appeared brown, and $\alpha-, \beta-$, and $\gamma$-ENaC were mainly expressed on alveolar epithelia. The number of cells expressing $\alpha-, \beta$-, and $\gamma$-ENaC was significantly decreased by LPS ( $\mathrm{p}<0.05$; fig. $5 \mathrm{a}-\mathrm{d}$ ) and markedly increased by netrin-1 ( $\mathrm{p}<0.05$; fig. $5 \mathrm{a}-\mathrm{d})$. However, the effect of netrin-1 was abolished by PSB1115 ( $p<0.05$; fig. $5 a-d)$.

Netrin-1 Stimulated the Expressions of $\alpha$-, $\beta$-, and $\gamma$-ENaC in vivo

Reverse transcription PCR (RT-PCR) and Western blotting were used to detect $\alpha-, \beta-$, and $\gamma$-ENaC expressions in mouse lung tissues. The expressions of $\alpha_{-}^{-}, \beta-$, and $\gamma$-ENaC mRNA and protein were all significantly decreased in mice with LPS intratracheal instillation ( $\mathrm{p}<0.05$; fig. 6a, b). Netrin-1 markedly upregulated the expressions of $\alpha$-, $\beta$-, and $\gamma$-ENaC mRNA and protein levels but was blocked by PSB1115 ( $<<0.05$; fig. 6a, b).

Netrin-1 Stimulated the Expressions of $\alpha-, \beta$-, and $\gamma$-ENaC in vitro

RT-PCR and Western blotting were used to detect $\alpha$-, $\beta$-, and $\gamma$-ENaC expressions in MLE- 12 cells. The expressions of $\alpha-, \beta$-, and $\gamma$-ENaC mRNA and protein were sig- 
Fig. 2. Effect of exogenous netrin-1 on the morphology of the lung $24 \mathrm{~h}$ after LPS or saline intratracheal instillation (magnification $\times 400$ ). a Control group: no obvious changes were observed. LPS group: conspicuous inflammatory cell infiltration, alveolar septa thickening, patchy hemorrhage, and intra-alveolar edema were found. LN group: netrin-1 alleviated LPSinduced ALI significantly. LPN group: PSB1115 significantly blocked the effect of netrin-1. b Lung injury evaluation: netrin-1 significantly reduced the LPS-induced increase in lung injury score. The effect of netrin-1 was blocked by PSB1115 ( $\mathrm{n}=5$ per group). Data are presented as means \pm SD. $* \mathrm{p}<0.05$ compared to the control group. ${ }^{\Delta} \mathrm{p}<0.05$ compared to the LPS group. ${ }^{\Phi} \mathrm{p}<0.05$ compared to the LN group.

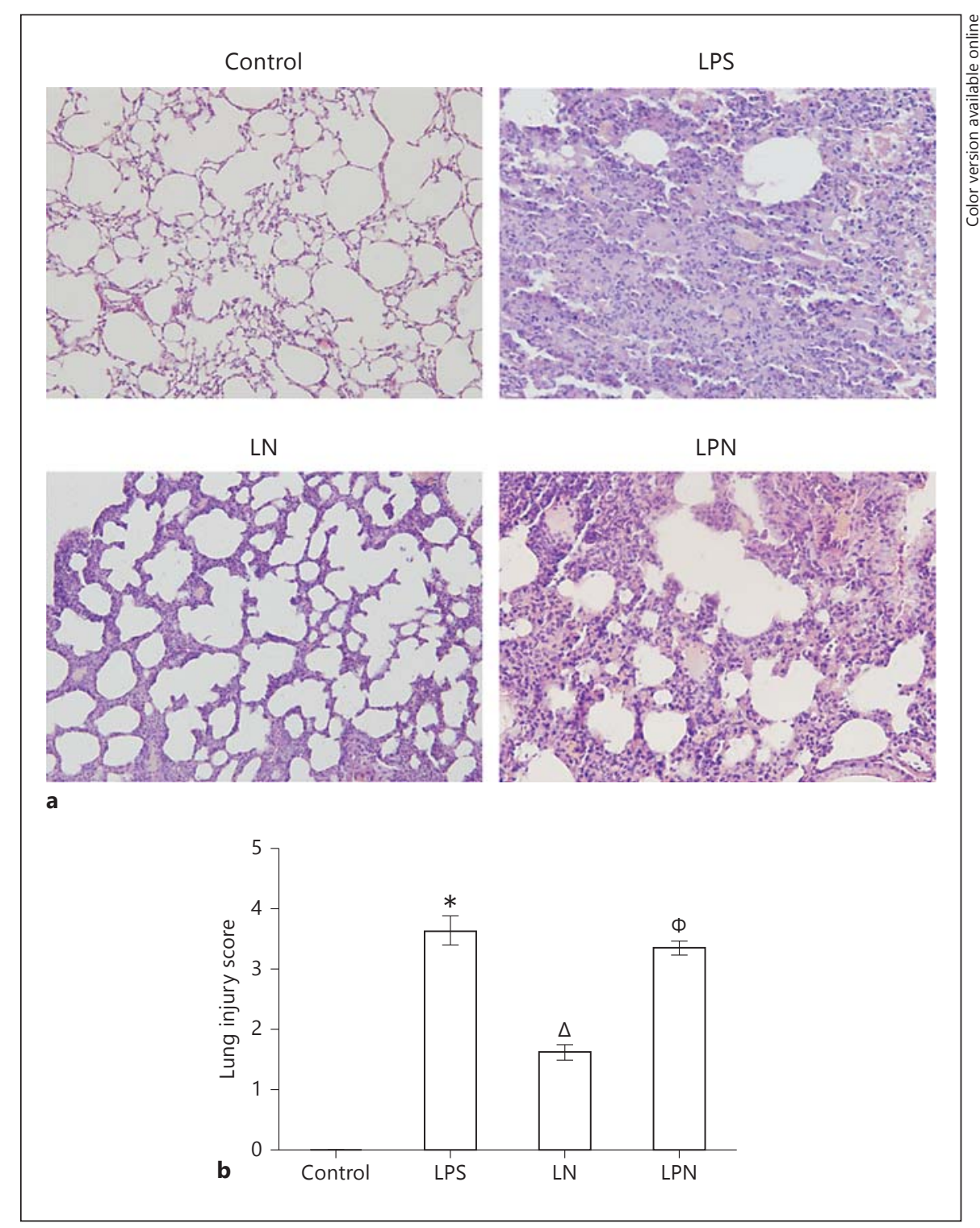

\section{Discussion}

In the current study, we demonstrated that netrin-1 plays a therapeutic role in LPS-induced ALI by accelerating $\mathrm{AFC}$ mediated by $\mathrm{ENaC}$ and alleviating the inflammation, and both are achieved via the activation of A2BAR.

ALI and ARDS are common complications in critical patients, with a high lethality. Based on pathophysiologically oriented views, ALI was divided into 2 types - a direct type and an indirect type. Direct ALI with a pulmonary origin accounts for approximately $55 \%$ of all ALI cases, while indirect ALI accounts for $20 \% ; 21 \%$ of cases 


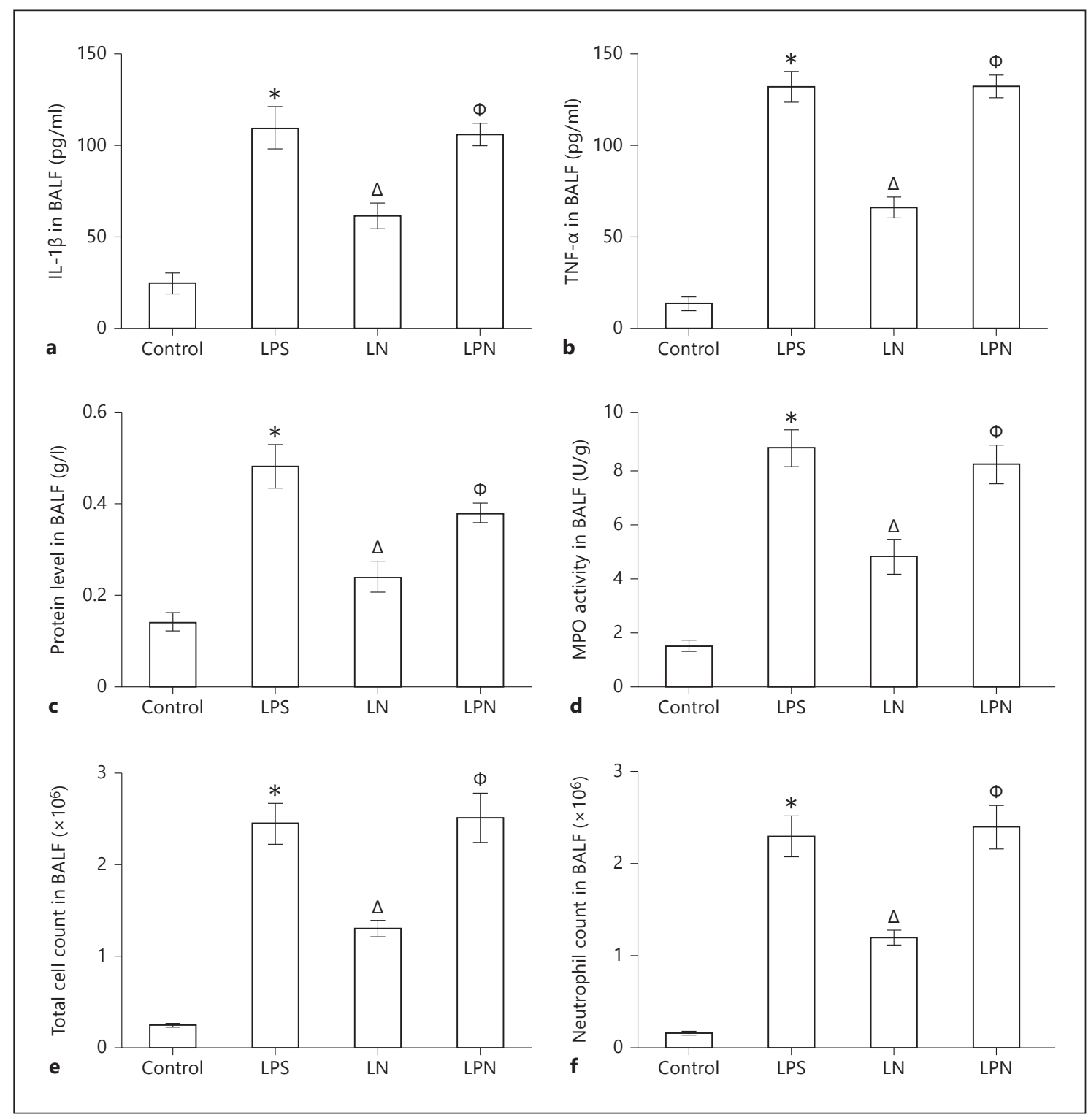

Fig. 3. Measurement of IL-1 $\beta$ (a), TNF- $\alpha$ (b), protein levels (c), MPO activity (d), the total cell count (e), and the neutrophil count (f) in BALF $24 \mathrm{~h}$ after LPS or saline treatment ( $\mathrm{n}=5$ per group).
Data are presented as means $\pm \mathrm{SD} .{ }^{*} \mathrm{p}<0.05$ compared to the control group. ${ }^{\Delta} \mathrm{p}<0.05$ compared to the LPS group. ${ }^{\Phi} \mathrm{p}<0.05$ compared to the LN group. appear to be due to mixed factors contributing to ALI, and the remaining $4 \%$ have no distinctive underlying pathophysiology [32]. However, in both kinds of ALI, pulmonary inflammation and pulmonary edema are the two primary pathological features [20, 33, 34].

Composed of polysaccharides and lipids, LPS is the main component of the cell walls of Gram-negative bacteria. Here we used LPS to model the effect of Gram-negative bacteria, a usual cause of the induction of ALI in humans, to imitate ALI in mice $[35,36]$. LPS stimulates macrophages to produce cytokines including IL- $1 \beta$ and TNF- $\alpha$, which play important roles in the pathogenesis in most cases of ALI. IL- $1 \beta$ and TNF- $\alpha$ upregulate adhesion molecules both on pulmonary vascular endothelium and on alveolar epithelium. The adhesion molecules on vascular endothelium enhance the adhesive ability of polymorphonuclear leukocytes and facilitate their transmigration to interstitial. Moreover, the adhesion molecules on alveolar epithelium enhance the adhesive capacity of alveolar macrophages to strengthen the amount of cyto- 


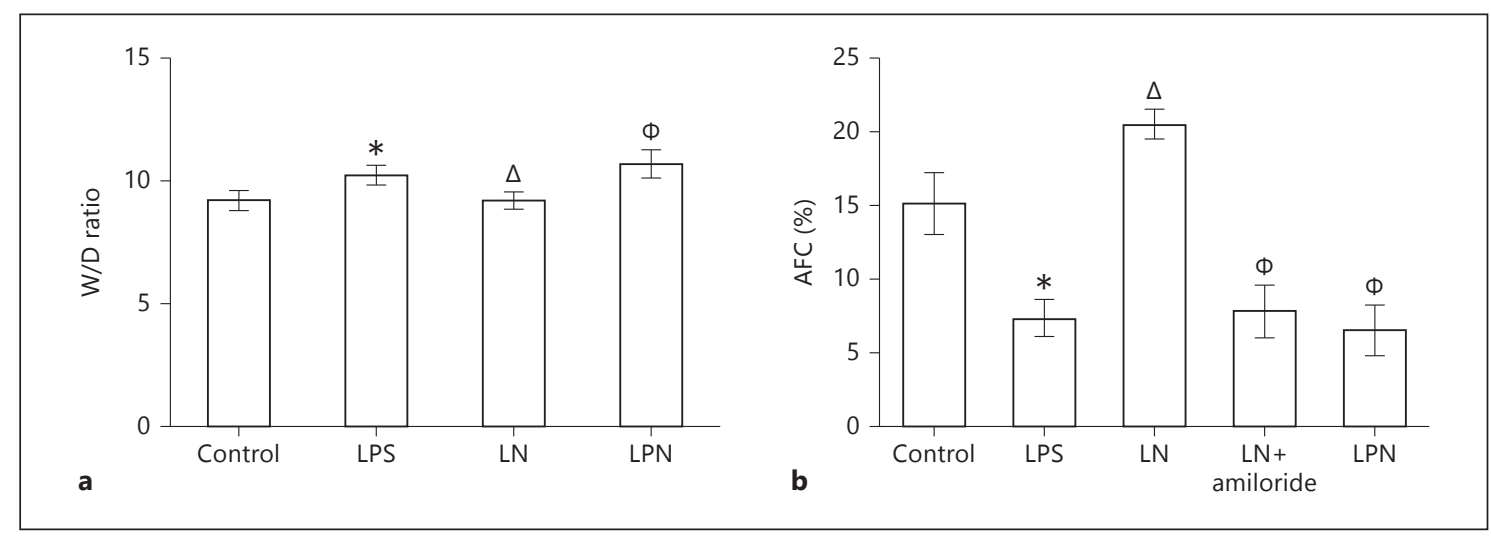

Fig. 4. Effect of exogenous netrin- 1 on pulmonary edema and AFC in LPS-induced ALI in mice ( $\mathrm{n}=5$ per group). a W/D ratio $24 \mathrm{~h}$ after LPS or saline intratracheal instillation. b AFC $24 \mathrm{~h}$ after LPS or saline intratracheal instillation. In the LN+amiloride group, amiloride $\left(5 \times 10^{-4} \mathrm{M}\right)$ was injected into the alveolar spaces. Data are presented as means $\pm \mathrm{SD} .{ }^{*} \mathrm{p}<0.05$ compared to the control group. ${ }^{\Delta} \mathrm{p}<0.05$ compared to the LPS group. ${ }^{\Phi} \mathrm{p}<0.05$ compared to the $\mathrm{LN}$ group.
Fig. 5. Effect of exogenous netrin-1 on the expression of $\alpha-\mathrm{ENaC}(\mathbf{a}), \beta-\mathrm{ENaC}(\mathbf{b})$, and $\gamma$-ENaC (c) proteins in mouse lung $24 \mathrm{~h}$ after LPS or saline intratracheal instillation $(\times 400)$. The number of positive cells (brown immunostained) was counted in 5 random high-power fields of each section ( 5 sections in each group from 5 respective mice). The quantities of positive cells expressing $\alpha-, \beta$-, and $\gamma$-ENaC were all significantly reduced in the LPS group compared to the control group. Netrin-1 increased the number of cells expressing $\alpha$-, $\beta$-, and $\gamma$-ENaC obviously and its effect was inhibited by PSB1115. Data are presented as means $\pm \mathrm{SD} .{ }^{*} \mathrm{p}<0.05$ compared to the control group. ${ }^{\Delta} \mathrm{p}<0.05$ compared to the LPS group. ${ }^{\Phi} \mathrm{p}<0.05$ compared to the $\mathrm{LN}$ group (d).

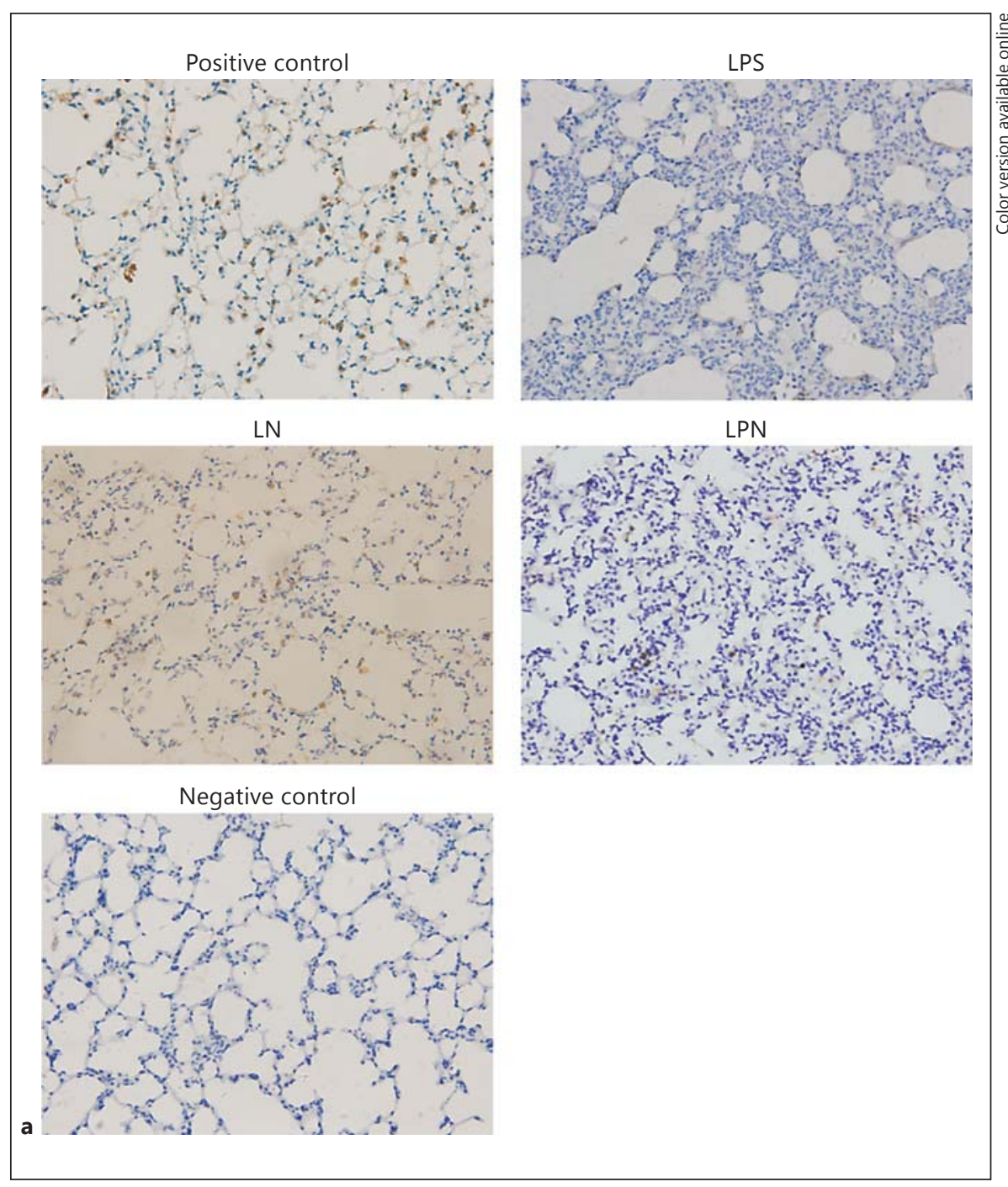

(For figures $5 b-d$ see next pages.) 


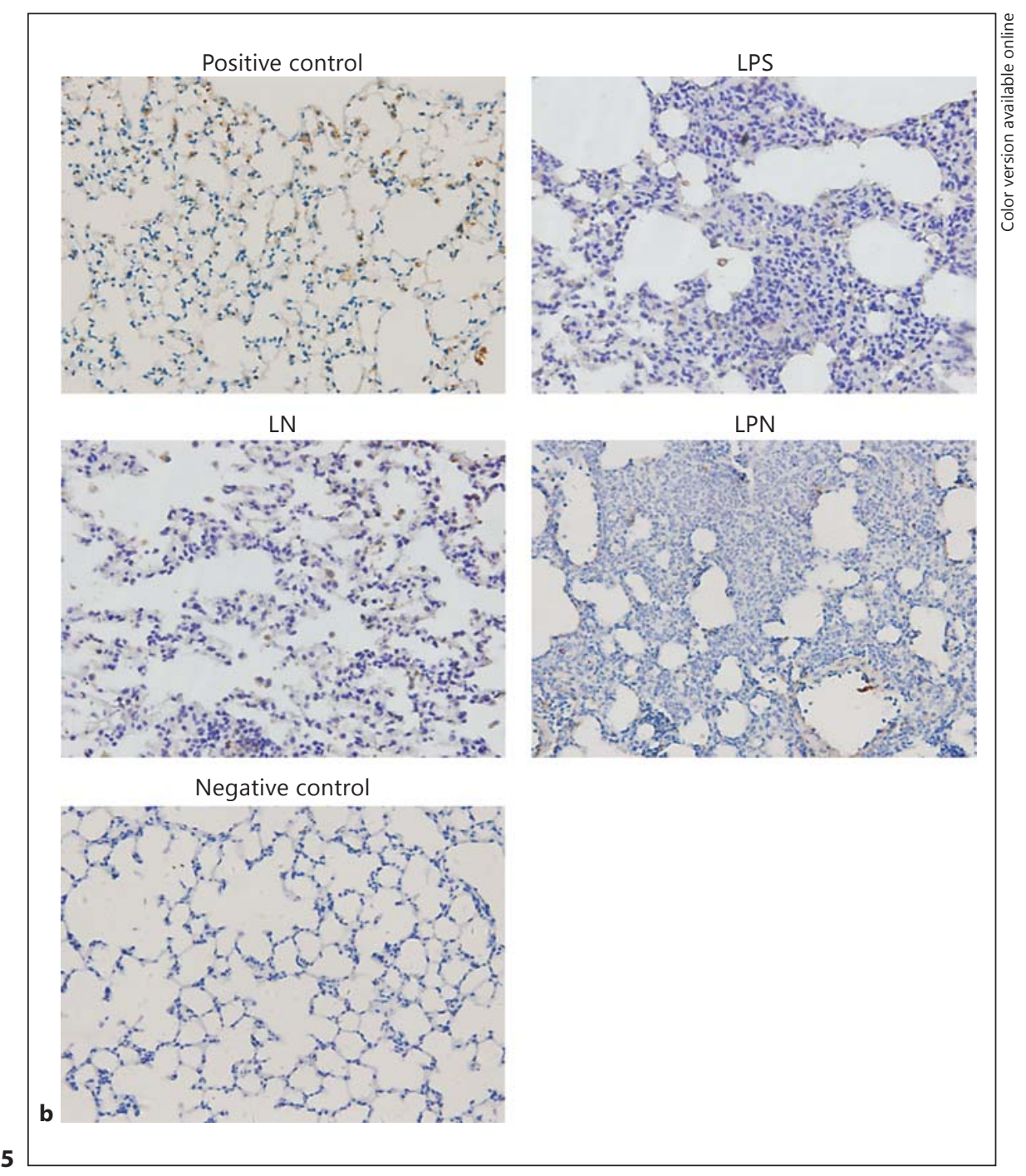

kines and chemokines [37]. The polymorphonuclear leukocytes infiltrate toward the inflammation sites and release various oxidation enzymes including MPO enzymes, resulting in tissue damage and increased permeability of the vascular endothelia. Consequently, the neutrophils, inflammatory cytokines, MPO activity, and protein content in BALF are all increased with LPS stimulation, which was also seen in our experiment.

Netrin-1 is a newly found negative regulator of neutrophil trafficking. Rosenberger et al. [38] first revealed that a hypoxia-induced increase in netrin-1 has anti-inflammatory effects exerted via an interaction with A2BAR expressed on polymorphonuclear neutrophils (polymorphonuclear leucocytes) to attenuate cytokine production and neutrophil transepithelial migration. Supporting this discovery, an anti-inflammatory effect of netrin- 1 has also been observed in models of acute experimental colitis [39], acute kidney injury [40], and diabetic nephropathy [41]. Netrin-1 was robustly induced due to hypoxia in the above conditions and directly limited the trafficking of neutrophils to ameliorate inflammation through A2BAR. In mice with partial netrin-1 deficiency, the conditions were more severe and exogenous netrin-1 alleviated the development of these diseases [39-41]. Meanwhile, a lack of functional A2BAR was proven to abrogate the protective effect of netrin-1 in these models, emphasizing the necessary role of A2BAR in these processes. On the contrary, our and previous research found that pulmonary netrin-1 was repressed during periods of LPS-induced ALI [15] and Staphylococcus aureus-induced lung inflammation [30]. The difference may be attributed to the different patho- 


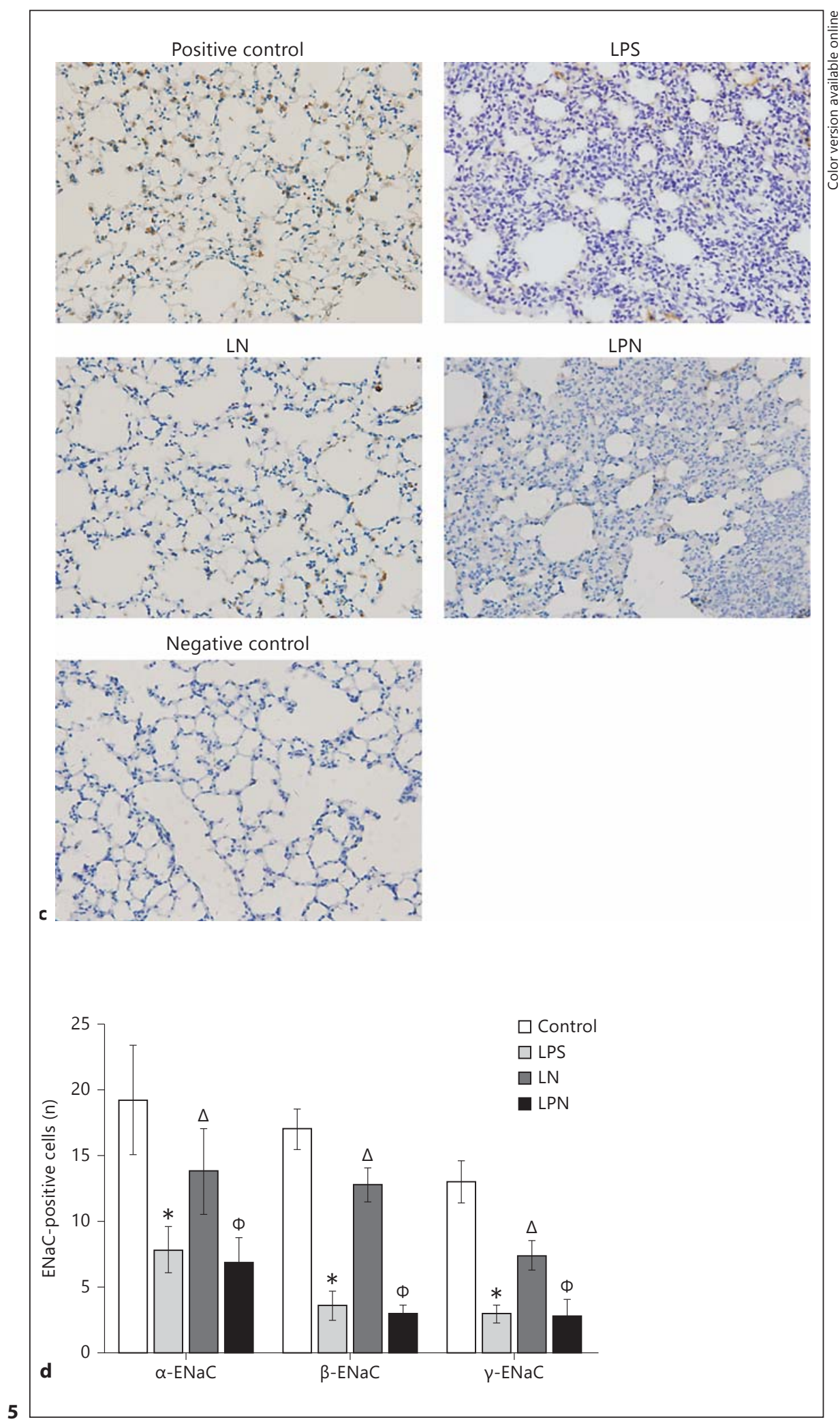




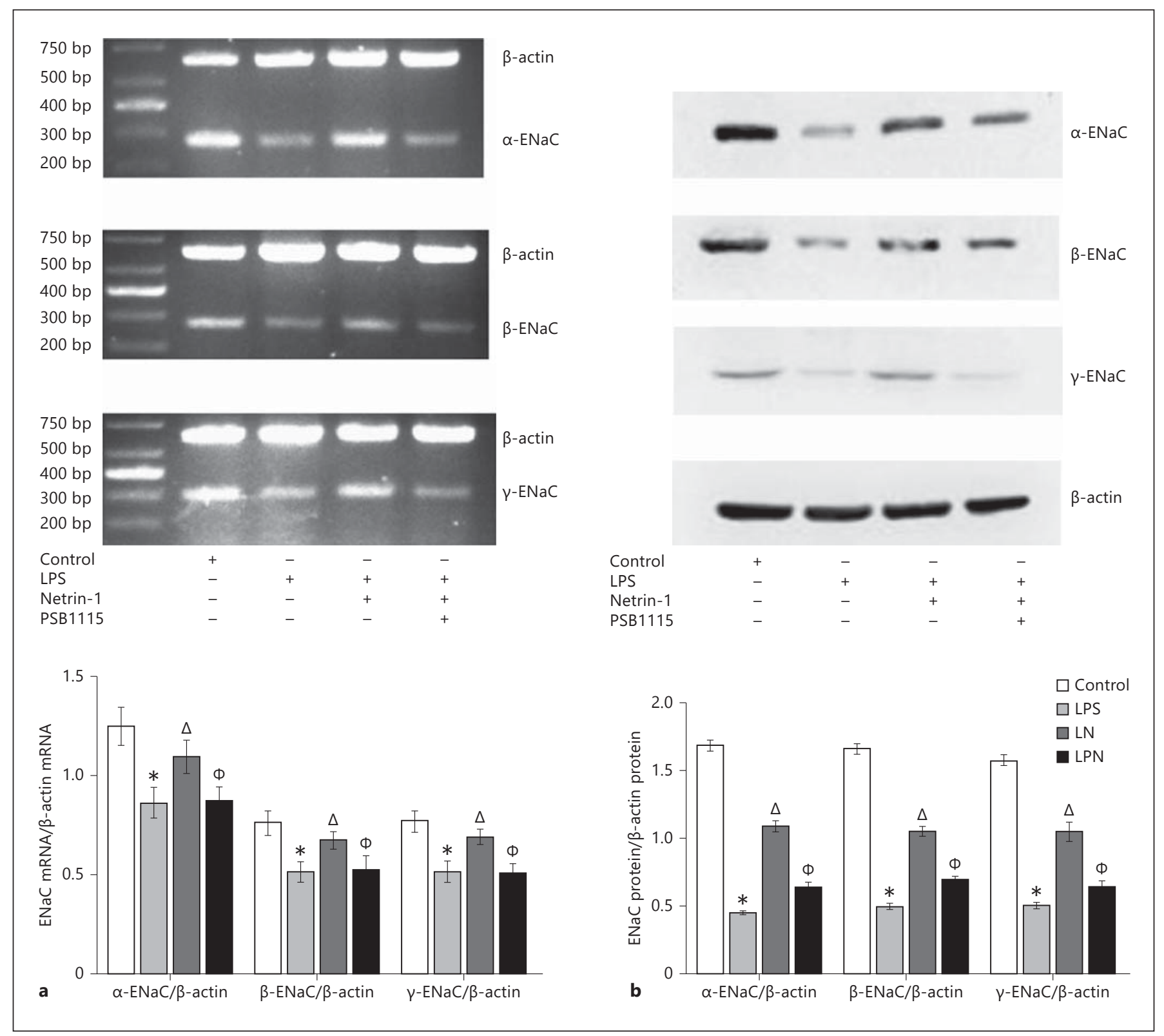

Fig.6. The expressions of $\alpha-, \beta-$, and $\gamma$-ENaC mRNA (a) and protein (b) in mouse lungs were determined by RT-PCR or Western blotting $24 \mathrm{~h}$ after LPS or saline intratracheal instillation $(n=5$ per

group). Data are presented as means \pm SD. ${ }^{*} \mathrm{p}<0.05$ compared to the control group. ${ }^{\Delta} \mathrm{p}<0.05$ compared to the LPS group. ${ }^{\Phi} \mathrm{p}<0.05$ compared to the LN group.

geneses and disease models. Under conditions of hypoxia, netrin- 1 is induced by a mechanism dependent on hypoxia-induced factor-1 $\alpha$ [38]. In LPS-induced ALI, inflammatory cytokines amplify the combination of NF$\kappa \mathrm{B}$ with the promoter of the NTN1 gene [15], repressing NTN1 transcription and the consequent netrin-1 protein synthesis. However, we also found the neutrophil recruitment by LPS was markedly inhibited by exogenous

netrin-1. The protein content, MPO enzyme activities, and inflammatory mediators in BALF were all decreased by netrin-1. All of these results demonstrated that, during ALI, reconstitution with exogenous netrin-1 could effectively postpone the inflammation process and alleviate the outbreak of inflammation. However, pretreatment with the specific A2BAR antagonist PSB1115 thirty minutes before netrin-1 abolished the netrin-1 in- 


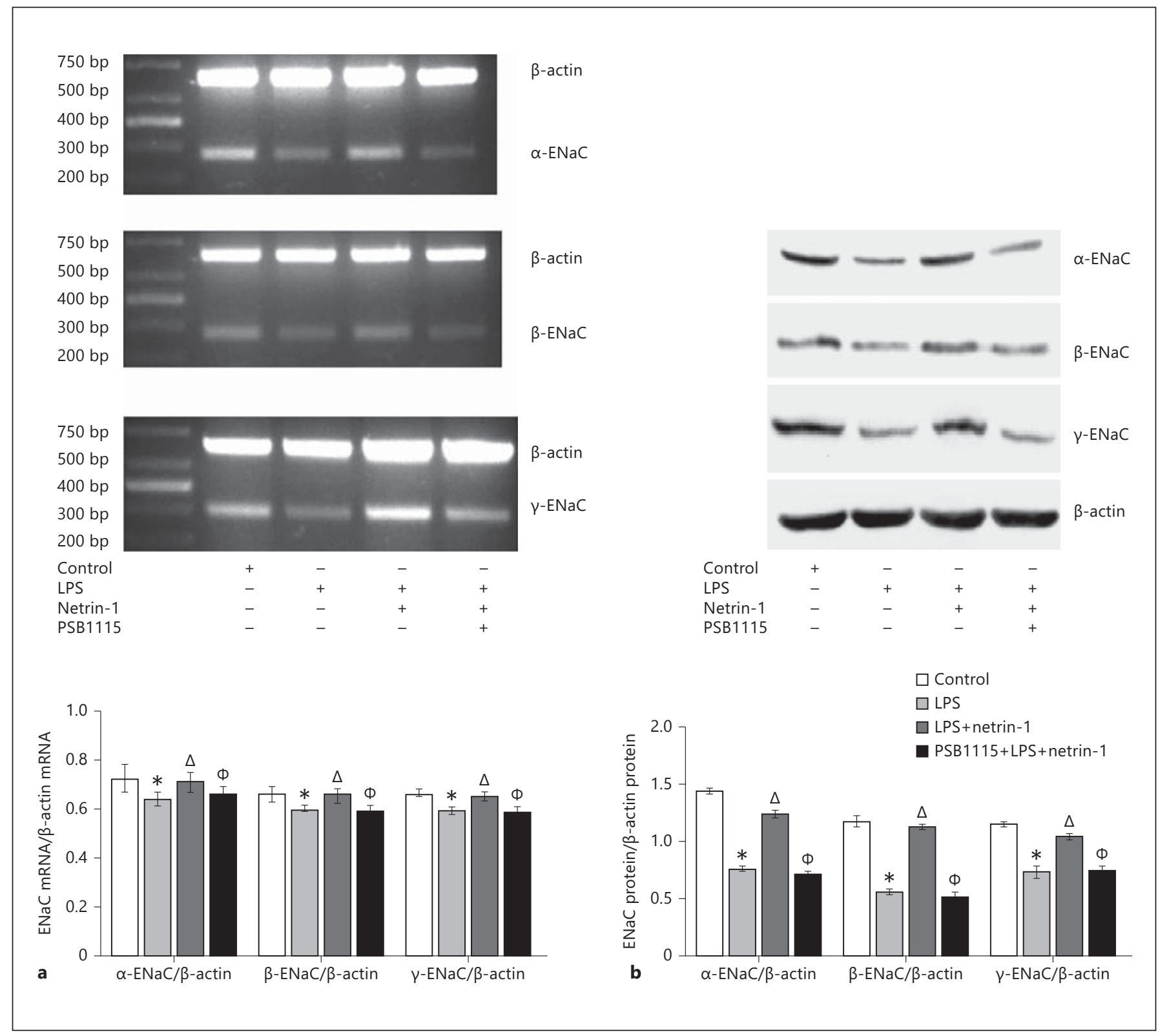

Fig. 7. The expressions of $\alpha^{-}, \beta_{-}$, and $\gamma$-ENaC mRNA (a) and protein (b) in MEL-12 cells were determined by RT-PCR or Western blotting $24 \mathrm{~h}$ after treatment ( $\mathrm{n}=5$ per group). Data are presented

duced-reduction of IL-1 $\beta$, TNF- $\alpha$, neutrophils counts, and MPO activity caused by LPS, indicating that the protective role of netrin-1 during ALI was dependent on A2BAR. A2BAR is one of 4 distinct adenosine receptors; the others include A1AR, A2AAR, and A3AR. A1AR and $A 3 A R$ are $\mathrm{Gi} / \mathrm{o}$ coupled and inhibit the formation of cAMP, whereas A2AAR and A2BAR are Gs coupled and promote the formation of cAMP. Through the activation

as means \pm SD. ${ }^{*} \mathrm{p}<0.05$ compared to the control group. ${ }^{\Delta} \mathrm{p}<0.05$ compared to the LPS group. ${ }^{\Phi} \mathrm{p}<0.05$ compared to the LPS+netrin-1 group.

of A2AAR on inflammatory cells [42] and the activation of A2BAR on epithelium or endothelium [31, 43, 44], adenosine signaling plays a protective role in models of ischemia and reperfusion. Through A2AAR and A2BAR, adenosine signaling exerts anti-inflammatory and barrier-protective effects during intestinal inflammation [45, 46]. In addition, through $\mathrm{A} 2 \mathrm{BAR}$, adenosine signaling accelerates AFC and attenuates capillary-alveolar per- 


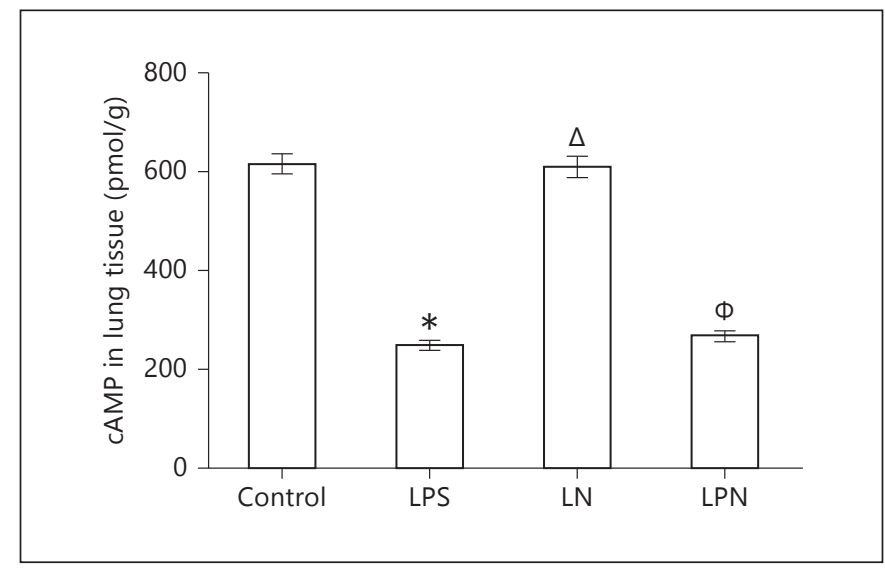

Fig. 8. The cAMP levels in murine lungs were detected by ELISA $24 \mathrm{~h}$ after LPS or saline intratracheal instillation ( $\mathrm{n}=5$ per group). Data are presented as means $\pm \mathrm{SD}$. ${ }^{*} \mathrm{p}<0.05$ compared to the control group. ${ }^{\Delta} \mathrm{p}<0.05$ compared to the LPS group. ${ }^{\Phi} \mathrm{p}<0.05$ compared to the LN group.

meability in ventilator-induced lung injury [17]. However, the low affinity of A2BAR for adenosine makes it hard to activate $[47,48]$. Interestingly, netrin-1 can combine with A2BAR and activate it as well. Using ${ }^{125} \mathrm{I}-\mathrm{la}$ belled netrin-1, a previous study revealed that netrin-1 does not interact with the classical adenosine-binding site of $\mathrm{A} 2 \mathrm{~B}$ but rather interacts with a specific binding site to activate A2BAR and further signal to the downstream molecules [49].

As another important pathological change in ALI, pulmonary edema, an imbalance between increased exudation and decreased fluid absorption, was found in the LPS-induced ALI mouse model. We found that netrin-1 therapy could dampen the pulmonary edema in the LPSinduced ALI mouse model. The mechanism might still be obscure, but we supposed that two aspects accounted for this. On one hand, as previously mentioned, with proven anti-inflammatory effects in ALI, netrin-1 could alleviate the alveolar-capillary barrier damage resulting from the toxin products. The integrity of the barrier was relatively conserved, so the accumulation of protein-rich fluid was reduced accordingly. On the other hand, AFC, a process in which excrescent fluid is removed from the alveolar space [50], may be improved to accelerate fluid absorption. However, it is well accepted that among the multiple factors affecting AFC, ENaC is the most crucial and the rate-limiting step for $\mathrm{Na}^{+}$absorption, playing an important role in the maintenance of effective AFC [51-53]. Thus, we further investigated whether netrin-1 had any correlation with ENaC-related AFC in the LPS-induced
ALI models. Here we observed the upregulated effect of netrin-1 on AFC, resulting in decreased pulmonary edema in ALI models, in accordance with the finding that stimulation of AFC could reduce the lung water content [23]. Meanwhile, we found that the promotion of AFC by netrin-1 was abolished by amiloride, a specific ENaC inhibitor [54-56], confirming that the process is $\mathrm{ENaC}$ dependent. We also detected $\mathrm{ENaC}$ expression and found that it was decreased after stimulation with LPS both in vivo and in vitro, which is consistent with previous studies [20,34]. Netrin-1 treatment significantly increased $\alpha$-, $\beta-$, and $\gamma$-ENaC expression in vivo and in vitro. This all demonstrated that netrin-1 stimulates AFC via upregulation of amiloride-sensitive ENaC. However, the effect of netrin-1 was abolished by PSB1115, illustrating that A2BAR was necessarily involved in this process. Therefore, the link between $\mathrm{ENaC}$ and the A2BAR signaling pathway was further investigated.

After being activated by netrin-1, A2BAR stimulates adenylate cyclase which in turn increases the intracellular cAMP levels $[49,57,58]$. cAMP is an important second messenger which mediates the actions of many primary messengers. cAMP can activate specific protein kinases such as protein kinase $\mathrm{A}$, leading to the phosphorylation of many substrates [59]. In ALI, increased cAMP caused by various pharmacologic approaches has been verified to stimulate the clearance of alveolar fluid, which is partially dependent on the enhancement of amiloride-sensitive epithelial $\mathrm{Na}^{+}$transport by an increase in $\mathrm{ENaC}$ expression via gene transcription levels [60-62]. Meanwhile, increased cAMP levels also stimulate the translocation of $\mathrm{ENaC}$ to the cell surface [62-64]. Therefore, cAMP can upregulate ENaC via transcriptional as well as posttranscriptional levels. In the current research, LPS administration decreased the cAMP levels in mice lung tissue, while netrin-1 reversed the situation and PSB1115 prevented the effect of netrin-1. The changing tendency of CAMP was similar to changes in $\mathrm{ENaC}$ expression levels, supporting the finding that $\mathrm{ENaC}$ expression could be increased by cAMP [55-59]. These results demonstrated that, by activating A2BAR, netrin-1 increased cAMP levels to stimulate $\mathrm{ENaC}$ expression.

With the capacity to alleviate inflammation and promote edema absorption during ALI $[17,18]$, the activation of A2BAR is of great importance in ALI. However, the extremely short effective half-life period of its natural ligand adenosine poses a major limitation for its systemic use. Adenosine will be rapidly cleared once it is generated and secreted into the extracellular milieu [65]. Further- 
more, systemic use of adenosine has obvious side effects such as vasodilation and bradycardia, which prevent it from becoming a systemic anti-inflammatory drug [66]. Besides, the low affinity between A2BAR and adenosine makes it difficult to induce A2BAR signaling activation through adenosine [47, 48]. However, Corset et al. [49] found that A2BAR displays a specific binding site for netrin-1 which is distinct from the classical adenosine-binding site. Moreover, netrin- 1 can further activate A2BAR even in the presence of NECA (5-N-ethylcarboxamido adenosine, an adenosine receptor agonist) [49]. That is to say, A2BAR offers different sites for adenosine and netrin-1 to interact, respectively, to activate itself. Therefore, netrin-1 is an ideal substitution for adenosine to activate A2BAR. These results indicated that, through the A2BAR signaling pathway, netrin-1 could alleviate lung injury in LPS-induced ALI by attenuating inflammation and promoting ENaC-mediated AFC. However, when A2BAR was blocked, the beneficial effect of netrin-1 was abolished.

\section{Conclusion}

In summary, the present data demonstrate that netrin-1 could suppress inflammation to dampen the lung injury and increase the expression of $\mathrm{ENaC}$ to speed up the resolution of pulmonary edema in LPS-stimulated ALI mice or alveolar cells, both of which are beneficial for the prognosis of ALI/ARDS. Activation of A2BAR and an increase in cAMP levels are necessarily involved.

\section{Acknowledgements}

We thank all of the members of Wang's laboratory for valuable advice. This study was supported by a grant from the National Natural Science Foundation of China (grant No.81270141).

\section{Competing Interests}

All authors declare no conflict of interest relevant to this study.

\section{References}

1 Rubenfeld GD, Caldwell E, Peabody E, Weaver J, Martin DP, Neff M, et al: Incidence and outcomes of acute lung injury. N Engl J Med 2005;353:1685-1693.

-2 Berthiaume Y, Matthay MA: Alveolar edema fluid clearance and acute lung injury. Respir Physiol Neurobiol 2007;159:350-359.

-3 Berthiaume Y, Folkesson HG, Matthay MA: Lung edema clearance: 20 years of progress. Invited review: alveolar edema fluid clearance in the injured lung. J Appl Physiol 2002;93: 2207-2213.

4 Canessa CM, Schild L, Buell G, Thorens B, Gautschi I, Horisberger JD, et al: Amiloridesensitive epithelial $\mathrm{Na}^{+}$channel is made of three homologous subunits. Nature 1994;367: 463-467.

5 Matthay MA, Folkesson HG, Clerici C: Lung epithelial fluid transport and the resolution of pulmonary edema. Physiol Rev 2002;82:569600.

6 Hummler E, Barker P, Gatzy J, Beermann F, Verdumo C, Schmidt A, et al: Early death due to defective neonatal lung liquid clearance in alpha-ENaC-deficient mice. Nat Genet 1996; 12:325-328.

7 Randrianarison N, Clerici C, Ferreira C, Fontayne A, Pradervand S, Fowler-Jaeger N, et al: Low expression of the beta-ENaC subunit impairs lung fluid clearance in the mouse. Am J Physiol Lung Cell Mol Physiol 2008;294:L409-L416.

-8 Elias N, Rafii B, Rahman M, Otulakowski G, Cutz E, O'Brodovich H: The role of alpha-, beta-, and gamma-ENaC subunits in distal lung epithelial fluid absorption induced by pulmonary edema fluid. Am J Physiol Lung Cell Mol Physiol 2007;293:L537-L545.

-9 Serafini T, Kennedy TE, Galko MJ, Mirzayan C, Jessell TM, Tessier-Lavigne M: The netrins define a family of axon outgrowth-promoting proteins homologous to C. elegans UNC-6. Cell 1994;78:409-424.

10 Dalvin S, Anselmo MA, Prodhan P, Komatsuzaki K, Schnitzer JJ, Kinane TB: Expression of Netrin-1 and its two receptors DCC and $\mathrm{UNC} 5 \mathrm{H} 2$ in the developing mouse lung. Gene Expr Patterns 2003;3:279-283.

11 Liu Y, Stein E, Oliver T, Li Y, Brunken WJ, Koch M, et al: Novel role for Netrins in regulating epithelial behavior during lung branching morphogenesis. Curr Biol 2004;14:897-905.

12 De Breuck S, Lardon J, Rooman I, Bouwens L: Netrin-1 expression in fetal and regenerating rat pancreas and its effect on the migration of human pancreatic duct and porcine islet precursor cells. Diabetologia 2003;46:926-933.

13 Yebra M, Montgomery AM, Diaferia GR, Kaido T, Silletti S, Perez B, et al: Recognition of the neural chemoattractant Netrin-1 by integrins alpha6beta4 and alpha3beta1 regulates epithelial cell adhesion and migration. Dev Cell 2003;5:695-707.

14 Srinivasan K, Strickland P, Valdes A, Shin GC, Hinck L: Netrin-1/neogenin interaction stabilizes multipotent progenitor cap cells during mammary gland morphogenesis. Dev Cell 2003;4:371-382.

15 Mirakaj V, Thix CA, Laucher S, Mielke C, Morote-Garcia JC, Schmit MA, et al: Netrin-1 dampens pulmonary inflammation during acute lung injury. Am J Respir Crit Care Med 2010;181:815-824.

16 Mutz C, Mirakaj V, Vagts DA, Westermann $\mathrm{P}$, Waibler K, Konig K, et al: The neuronal guidance protein netrin-1 reduces alveolar inflammation in a porcine model of acute lung injury. Crit Care 2010;14:R189.

17 Eckle T, Grenz A, Laucher S, Eltzschig HK: A2B adenosine receptor signaling attenuates acute lung injury by enhancing alveolar fluid clearance in mice. JClin Invest 2008;118:3301-3315.

18 Schingnitz U, Hartmann K, Macmanus CF, Eckle T, Zug S, Colgan SP, et al: Signaling through the $\mathrm{A} 2 \mathrm{~B}$ adenosine receptor dampens endotoxin-induced acute lung injury. J Immunol 2010;184:5271-5279.

19 Zhang X, Huang H, Yang T, Ye Y, Shan J, Yin $\mathrm{Z}$, et al: Chlorogenic acid protects mice against lipopolysaccharide-induced acute lung injury. Injury 2010;41:746-752.

20 Deng W, Li CY, Tong J, Zhang W, Wang DX: Regulation of ENaC-mediated alveolar fluid clearance by insulin via PI3K/Akt pathway in LPS-induced acute lung injury. Respir Res 2012;13:29.

21 Rhee CK, Lee SH, Yoon HK, Kim SC, Lee SY, Kwon SS, et al: Effect of nilotinib on bleomycin-induced acute lung injury and pulmonary fibrosis in mice. Respiration 2011;82:273-287.

22 Rui M, Duan YY, Zhang XH, Wang HL, Wang DP: Urinary trypsin inhibitor attenuates seawater-induced acute lung injury by influencing the activities of nuclear factor- $\mathrm{kB}$ and its related inflammatory mediators. Respiration 2012;83:335-343. 
23 Sakuma T, Hida M, Nambu Y, Osanai K, Toga $\mathrm{H}$, Takahashi K, et al: Effects of hypoxia on alveolar fluid transport capacity in rat lungs. J Appl Physiol 2001;91:1766-1774.

24 Sakuma T, Zhao Y, Sugita M, Sagawa M, Toga $\mathrm{H}$, Ishibashi $\mathrm{T}$, et al: Malnutrition impairs alveolar fluid clearance in rat lungs. Am J Physiol Lung Cell Mol Physiol 2004;286:L1268-L1274.

25 Parsey MV, Tuder RM, Abraham E: Neutrophils are major contributors to intraparenchymal lung IL-1 beta expression after hemorrhage and endotoxemia. J Immunol 1998; 160:1007-1013.

26 Zhu T, Wang DX, Zhang W, Liao XQ, Guan X, Bo $\mathrm{H}$, et al: Andrographolide protects against LPS-induced acute lung injury by inactivation of NF-kappaB. PLoS One 2013;8:e56407.

27 Kawedia JD, Yang F, Sartor MA, Gozal D, Czyzyk-Krzeska M, Menon AG: Hypoxia and hypoxia mimetics decrease aquaporin 5 (AQP5) expression through both hypoxia inducible factor-1alpha and proteasome-mediated pathways. PLoS One 2013;8:e57541.

$\checkmark 28$ de Seigneux S, Leroy V, Ghzili H, Rousselot $M$, Nielsen S, Rossier BC, et al: NF-kappaB inhibits sodium transport via down-regulation of SGK1 in renal collecting duct principal cells. J Biol Chem 2008;283:25671-25681.

-29 Gunther J, Petzl W, Zerbe H, Schuberth HJ, Koczan D, Goetze L, et al: Lipopolysaccharide priming enhances expression of effectors of immune defence while decreasing expression of pro-inflammatory cytokines in mammary epithelia cells from cows. BMC Genomics 2012;13:17.

- 30 Ly NP, Komatsuzaki K, Fraser IP, Tseng AA, Prodhan P, Moore KJ, et al: Netrin-1 inhibits leukocyte migration in vitro and in vivo. Proc Natl Acad Sci USA 2005;102:14729-14734.

- 31 Eckle T, Faigle M, Grenz A, Laucher S, Thompson LF, Eltzschig HK: A2B adenosine receptor dampens hypoxia-induced vascular leak. Blood 2008;111:2024-2035.

- 32 Brun-Buisson C, Minelli C, Bertolini G, Brazzi L, Pimentel J, Lewandowski K, et al: Epidemiology and outcome of acute lung injury in European intensive care units: results from the ALIVE study. Intensive Care Med 2004;30:51-61.

-33 Ware LB, Matthay MA: The acute respiratory distress syndrome. New Engl J Med 2000;342: 1334-1349.

-34 Zhu T, Zhang W, Wang DX: Insulin up-regulates epithelial sodium channel in LPS-induced acute lung injury model in rats by SGK1 activation. Injury 2012;43:1277-1283.

- 35 Rosenthal C, Caronia C, Quinn C, Lugo N, Sagy M: A comparison among animal models of acute lung injury. Crit Care Med 1998;26: 912-916.

- 36 Windsor AC, Mullen PG, Fowler AA: Acute lung injury: what have we learned from animal models? Am J Med Sci 1993;306:111-116.

-37 Ward PA: Acute lung injury: how the lung inflammatory response works. The Eur Respir J Suppl 2003;44:22s-23s.

- 38 Rosenberger P, Schwab JM, Mirakaj V, Masekowsky E, Mager A, Morote-Garcia JC, et al: Hypoxia-inducible factor-dependent induction of netrin-1 dampens inflammation caused by hypoxia. Nat Immunol 2009;10: 195-202.

39 Aherne CM, Collins CB, Masterson JC, Tizzano M, Boyle TA, Westrich JA, et al: Neuronal guidance molecule netrin-1 attenuates inflammatory cell trafficking during acute experimental colitis. Gut 2012;61:695-705.

40 Grenz A, Dalton JH, Bauerle JD, Badulak A, Ridyard D, Gandjeva A, et al: Partial netrin-1 deficiency aggravates acute kidney injury. PLoS One 2011;6:e14812.

41 Tak E, Ridyard D, Badulak A, Giebler A, Shabeka U, Werner T, et al: Protective role for netrin-1 during diabetic nephropathy. J Mol Med (Berl) 2013;91:1071-1080.

42 Wallace KL, Linden J: Adenosine A2A receptors induced on iNKT and NK cells reduce pulmonary inflammation and injury in mice with sickle cell disease. Blood 2010;116:5010-5020.

43 Grenz A, Osswald H, Eckle T, Yang D, Zhang $\mathrm{H}$, Tran ZV, et al: The reno-vascular A2B adenosine receptor protects the kidney from ischemia. PLoS Med 2008;5:e137.

44 Hart ML, Jacobi B, Schittenhelm J, Henn M, Eltzschig HK: Cutting edge: A2B adenosine receptor signaling provides potent protection during intestinal ischemia/reperfusion injury. J Immunol 2009;182:3965-3968.

45 Naganuma M, Wiznerowicz EB, Lappas CM, Linden J, Worthington MT, Ernst PB: Cutting edge: critical role for $\mathrm{A} 2 \mathrm{~A}$ adenosine receptors in the T cell-mediated regulation of colitis. J Immunol 2006;177:2765-2769.

46 Frick JS, MacManus CF, Scully M, Glover LE, Eltzschig HK, Colgan SP: Contribution of adenosine $\mathrm{A} 2 \mathrm{~B}$ receptors to inflammatory parameters of experimental colitis. J Immunol 2009; 182:4957-4964.

47 Fredholm BB, IJzerman AP, Jacobson KA, Klotz KN, Linden J: International Union of Pharmacology. 25. Nomenclature and classification of adenosine receptors. Pharmacol Rev 2001;53:527-552.

48 Fredholm BB, Irenius E, Kull B, Schulte G: Comparison of the potency of adenosine as an agonist at human adenosine receptors expressed in Chinese hamster ovary cells. Biochem Pharmacol 2001;61:443-448.

49 Corset V, Nguyen-Ba-Charvet KT, Forcet C, Moyse E, Chedotal A, Mehlen P: Netrin1-mediated axon outgrowth and cAMP production requires interaction with adenosine A2b receptor. Nature 2000;407:747-750.

50 Sartori C, Matthay MA: Alveolar epithelial fluid transport in acute lung injury: new insights. Eur Respir J 2002;20:1299-1313.

-51 Schild L, Kellenberger S: Structure function relationships of $\mathrm{ENaC}$ and its role in sodium handling. Adv Exp Med Biol 2001;502:305-314.

52 Otulakowski G, Rafii B, O’Brodovich H: Differential translational efficiency of ENaC subunits during lung development. Am J Respir Cell Mol Biol 2004;30:862-870.

53 Planes C, Leyvraz C, Uchida T, Angelova MA, Vuagniaux G, Hummler E, et al: In vitro and in vivo regulation of transepithelial lung alveolar sodium transport by serine proteases. Am J Physiol Lung Cell Mol Physiol 2005; 288:L1099-L1109.

54 Kelly O, Lin C, Ramkumar M, Saxena NC, Kleyman TR, Eaton DC: Characterization of an amiloride binding region in the alpha-subunit of ENaC. Am J Physiol Renal Physiol 2003;285:F1279-F1290.

55 Blanchard A, Frank M, Wuerzner G, Peyrard S, Bankir L, Jeunemaitre X, et al: Antinatriuretic effect of vasopressin in humans is amiloride sensitive, thus $\mathrm{ENaC}$ dependent. Clin J Am Soc Nephrol 2011;6:753-759.

56 Galizia L, Ojea A, Kotsias BA: Amiloride sensitive sodium channels $(\mathrm{ENaC})$ and their regulation by proteases (in Spanish). Medicina (B Aires) 2011;71:179-182.

57 Comerford KM, Lawrence DW, Synnestvedt $\mathrm{K}$, Levi BP, Colgan SP: Role of vasodilatorstimulated phosphoprotein in PKA-induced changes in endothelial junctional permeability. FASEB J 2002;16:583-585.

58 Fredholm BB, Abbracchio MP, Burnstock G, Daly JW, Harden TK, Jacobson KA, et al: Nomenclature and classification of purinoceptors. Pharmacol Rev 1994;46:143-156.

59 Tang HF, Lu JJ, Tang JF, Zheng X, Liang YQ, Wang XF, et al: Action of a novel PDE4 inhibitor ZL-n-91 on lipopolysaccharide-induced acute lung injury. Int Immunopharmacol 2010;10:406-411.

60 Dagenais A, Denis C, Vives MF, Girouard S, Masse C, Nguyen T, et al: Modulation of alpha-ENaC and alphal- $\mathrm{Na}^{+}-\mathrm{K}^{+}$-ATPase by cAMP and dexamethasone in alveolar epithelial cells. Am J Physiol Lung Cell Mol Physiol 2001;281:L217-L230.

61 Itani OA, Auerbach SD, Husted RF, Volk KA, Ageloff S, Knepper MA, et al: Glucocorticoidstimulated lung epithelial $\mathrm{Na}(+)$ transport is associated with regulated $\mathrm{ENaC}$ and sgk1 expression. Am J Physiol Lung Cell Mol Physiol 2002;282:L631-L641.

62 Thomas CP, Campbell JR, Wright PJ, Husted RF: cAMP-stimulated $\mathrm{Na}^{+}$transport in $\mathrm{H} 441$ distal lung epithelial cells: role of PKA, phosphatidylinositol 3-kinase, and sgk1. Am J Physiol Lung Cell Mol Physiol 2004;287: L843-L851.

63 Snyder PM: Liddle's syndrome mutations disrupt cAMP-mediated translocation of the epithelial $\mathrm{Na}(+)$ channel to the cell surface. J Clin Invest 2000;105:45-53.

64 Morris RG, Schafer JA: cAMP increases density of $\mathrm{ENaC}$ subunits in the apical membrane of MDCK cells in direct proportion to amiloride-sensitive $\mathrm{Na}(+)$ transport. J Gen Physiol 2002;120:71-85.

65 Mirakaj V, Gatidou D, Potzsch C, Konig K, Rosenberger P: Netrin-1 signaling dampens inflammatory peritonitis. J Immunol 2011; 186:549-555

66 Belardinelli L, Shryock JC, Song Y, Wang D, Srinivas M: Ionic basis of the electrophysiological actions of adenosine on cardiomyocytes. FASEB J 1995;9:359-365. 